\title{
Aspects Regarding the Beneficial Effect of Reflexology in Low Back Pain
}

\section{Şerban GLIGOR ${ }^{1}$, Silviu ISTRATE ${ }^{2}$}

\begin{abstract}
Reflexology is based on the digital pressure on certain reflex points situated on the sole of the foot, which represents a "map" of the entire body. The aim of this paper is to highlight the importance of reflexology in low back pain treatment. To accomplish the objectives of this paper, a lot of 12 patients, of both genders, with low back pain, was formed. Out of these patients, $66.67 \%$ were male and $33.33 \%$ were female, the majority coming from an urban area (75\%). The average age \pm the standard deviation of the patients was $43.58 \pm 13.02$ years. The group of patients was subdivided into an experimental group, composed of 7 patients (58.33\%), who, besides the classic drug treatment, also underwent reflexology, and a control group, composed of 5 patients (41.67\%), who underwent only drug treatment. The treatment linked to reflexology was conducted by a single practitioner of reflexology, using the Morrell technique. Both in the case of the experimental group and in the control one there was a statistically significant reduction in finger to ground index $(p<0.01$, respectively $p<0.05)$. Also, there was a highly statistically significant reduction of pain $(p<0.01)$. Due to the small number of patients involved in the study, the data obtained cannot be generalised, as further studies are required to highlight the beneficial effect of reflexology in the case of low back pain.
\end{abstract}

Key words: reflexology, low back pain, finger to ground index

\section{Rezumat}

Reflexoterapia se bazează pe exercitarea digitală a unei presiuni asupra anumitor puncte reflexogene situate în talpa piciorului, aceasta reprezentând o „hartă” a întregului corp. Scopul lucrării este reprezentat de evidențierea importanței reflexoterapiei în tratarea pacienților cu durere lombară joasă. Pentru realizarea obiectivelor cercetării am constituit un lot de 12 pacienți, de ambele sexe, cu diagnosticul de durere lombară joasă. Dintre aceştia, 66,67\% au fost de sex masculin şi $33,33 \%$ de sex feminin, majoritatea provenind din mediul urban (75\%). Vârsta medie \pm deviația standard a pacienților a fost de 43,58 $\pm 13,02$ ani. Lotul de pacienți a fost subîmpărțit într-un lot experimental, format din 7 pacienți (58,33\%), care pe lângă tratamentul clasic medicamentos au urmat şi reflexoterapie şi un lot martor, format din 5 pacienți (41,67\%), care au urmat doar tratament medicamentos. Tratamentul reflexoterapeutic a fost efectuat de un singur reflexoterapeut, utilizând tehnica Morrell. Atât la pacienții lotului experimental, cât şi la pacienții lotului martor, s-au produs reduceri foarte semnificative statistic $(p<0.01)$ ale durerii finale față de cea inițială, dar totodată, s-au produs îmbunătățiri foarte semnificative statistic $(p<0.01)$ ale valorilor indicelui degete-sol la pacienții lotului de cercetare, pe când în cazul pacienților din lotul martor, îmbunătățirea acestui indice a fost doar semnificativă statistic $(p<0.05)$. Datorită numărului mic de pacienți luați în studiu, datele obținute nu pot fi generalizate, fiind necesare studii ulterioare de mai mare amploare pentru evidențierea efectului benefic al reflexoterapiei în durerea lombară joasă.

Cuvinte cheie: reflexoterapie, durere lombară joasă, index degete-sol

\footnotetext{
${ }^{1}$ MD, Lecturer, PhD, Physical Education and Sport Faculty, West University of Timisoara, e-mail: gligor_serban@yahoo.com

${ }^{2}$ Physiotherapist, reflexologist, Hunedoara
} 


\section{Introduction}

Reflexology is a therapeutic method which complements conventional medicine and has its origins in ancient China. It is based on the digital pressure on certain reflex points situated on the sole of the foot, which represents a "map" of the entire body. The same principle can be applied to hands and ears. [1,2] Thus, massaging the reflex points from the sole of the foot can influence the distal areas of the body by modifying the flux of energy (Qi) which travels through the body by energy meridians.

The possible mechanism of action involves the conversion of the generated energy (information) by applying mechanical pressure on the reflex points under nervous impulse which is transmitted to superior integrative structures, via the autonomous nervous system. Thus, reflexology seems to act through the redistribution of the blood flow at the level of the affected organs. [3, 4]

At the same time, reflexology determines areal decongestion, increase of the cell membranes' permeability, with an increased local influx of nutrients, relief of toxic substances from the organism, neurovegetative rebalance, improvement of metabolism and reconstruction of the organism's defence potential. $[5,6]$

One of the frequent use of reflexology is the chronic low back pain, a major health problem of contemporary society. Chronic low back pain is defined as an unsolved episode of back pain which has been lasting for over 12 weeks. A significant number of patients orient themselves towards alternative treatment methods of this disease, either because they are not satisfied with classic therapy or because they have high confidence in this alternative type of treatment. [7]

The aim of this paper is to highlight the importance of reflexology in low back pain treating. In order to achieve this purpose, the research had the following aims:

- to organise the group of patients

- to establish the means of evaluating the pain in the lower back area

- to establish an individualised program of reflexology

- to analyse and interpret the results

- to elaborate the conclusions and recommendations.

\section{Material and methods}

The study was conducted within the "Salted Baths Rehabilitation Centre" from the County Hospital in Deva; however, some patients from the research group underwent the treatment at home. The length of the treatment was 10 months, from July 2010 to April 2011, with two hospitalizations (lasting 15 days) in the rehabilitation centre and the rest of the treatment being conducted at the patients' homes. In order to accomplish the objectives of the research, a group of 12 patients was formed; the patients were of both genders and were diagnosed with low back pain. Out of these patients, $66.67 \%$ were male and $33.33 \%$ were female, the majority coming from an urban area (75\%). The average age \pm the standard deviation of the patients was $43.58 \pm$ 13.02 years, with age limits between 21 and 60 .

The lot of patients was subdivided into an experimental group, composed of 7 patients (58.33\%), who, besides the clasic drug treatment, also underwent reflexology, and a control group, composed of 5 patients (41.67\%), who underwent only drug treatment. The experimental group was composed of 4 women and 3 men, with an average age \pm the standard deviation of $49.71 \pm 5.55$ years; the control group consisted of 4 men and 1 woman, with an average age \pm the standard deviation of $35 \pm 16.20$ years. (table I) 
Table I. The group of patients (experimental and control group)

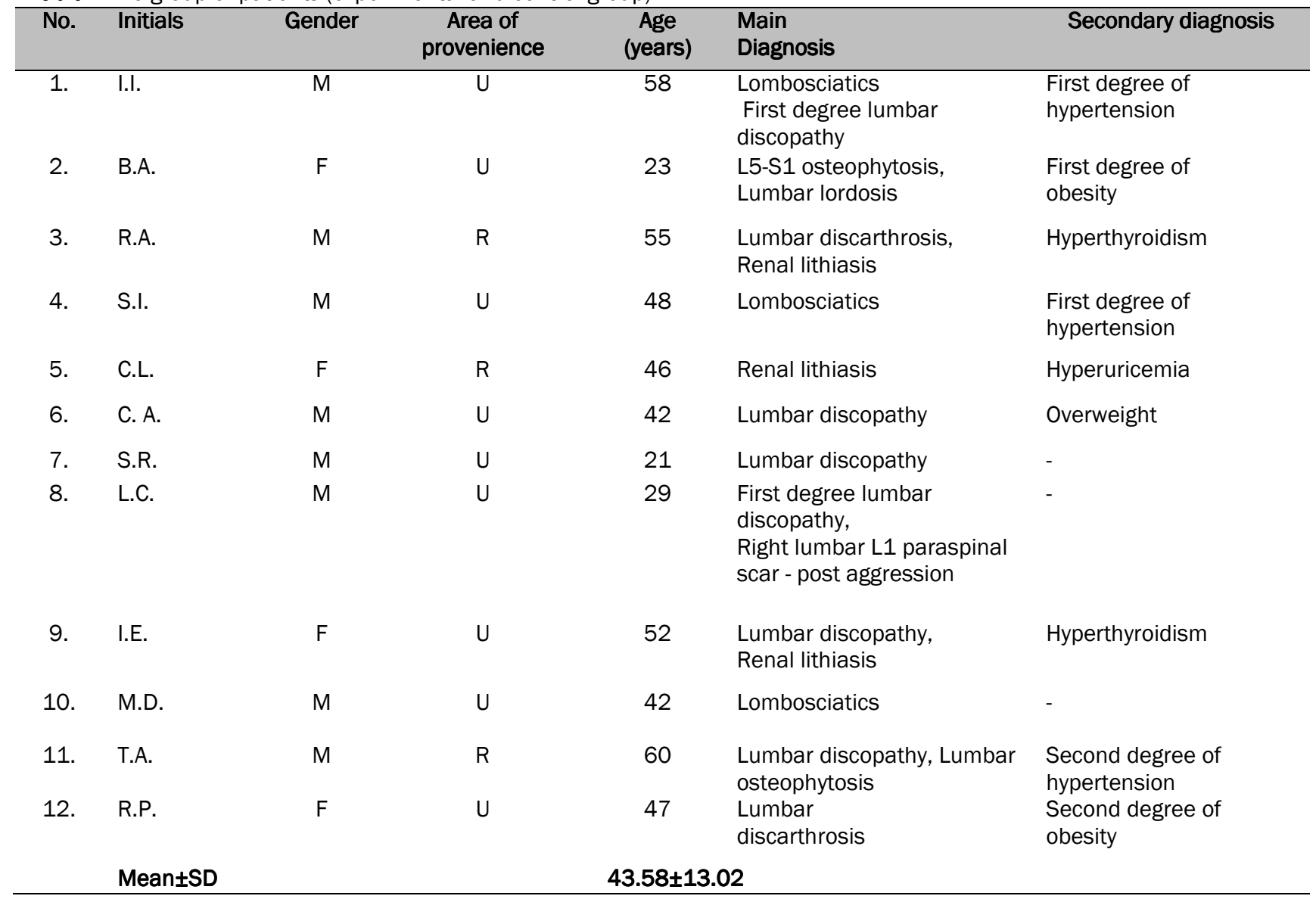

Legend: $\mathrm{R}$ - rural area, $\mathrm{U}$ - urban area, F - female, M - male, SD - standard deviation

The drug treatment consisted of antihypertensive therapy, antialgic therapy, antidepressants, nonsteroidal anti-inflammatory drugs and allopurinol.

Relaxation techniques were applied at the beginning of each session of reflexology: the back and forth technique, flexing the diaphragm and solar plexus, and rotating the ankle. The reflex therapy treatment was conducted by only one practitioner of reflexology using the Morrell technique, which implies the firm but gentle application of a compression by the hands of the therapist on the reflex points from the soles of the feet, which correspond to other parts of the body. (table II)

The effects of the therapy on low back pain have been evaluated with the help of the VAS (Visual Analogue Scale), used for evaluating pain, and with the help of the finger to ground index.
Table II. The treatment performed by both patient groups

\begin{tabular}{cccccc} 
No. & Initials & Gender & $\begin{array}{c}\text { Age } \\
\text { (year) }\end{array}$ & $\begin{array}{c}\text { Drug } \\
\text { treatment }\end{array}$ & $\begin{array}{c}\text { Reflex } \\
\text { therapy }\end{array}$ \\
\hline 1. & I.I. & $\mathrm{M}$ & 58 & $\mathrm{x}$ & $\mathbf{x}$ \\
2. & B.A. & $\mathrm{F}$ & 23 & $\mathrm{x}$ & - \\
3. & R.A. & $\mathrm{M}$ & 55 & $\mathrm{x}$ & $\mathbf{x}$ \\
4. & S.I. & $\mathrm{M}$ & 48 & $\mathrm{x}$ & $\mathbf{x}$ \\
5. & C.L. & $\mathrm{F}$ & 46 & $\mathrm{x}$ & $\mathbf{x}$ \\
6. & C. A. & $\mathrm{M}$ & 42 & $\mathrm{x}$ & - \\
7. & S.R. & $\mathrm{M}$ & 21 & $\mathrm{x}$ & - \\
8. & L.C. & $\mathrm{M}$ & 29 & $\mathrm{x}$ & - \\
9. & I.E. & $\mathrm{F}$ & 52 & $\mathrm{x}$ & $\mathbf{x}$ \\
10. & M.D. & $\mathrm{M}$ & 42 & $\mathrm{x}$ & $\mathbf{x}$ \\
11. & T.A. & $\mathrm{M}$ & 60 & $\mathrm{x}$ & - \\
12. & R.P. & $\mathrm{F}$ & 47 & $\mathrm{x}$ & $\mathbf{x}$ \\
\hline
\end{tabular}

The evaluations were conducted initially 5 months after the study began and at the study's end. VAS is a scale of psychometric response used to evaluate 
the subjective pain of the patients with various pathologies. It consists of a linear scale graded at the two ends with " 0 " and "10", where " 0 " means lack of any pain, while "10" means severe pain.

The finger to ground index measures the distance between the tip of the fingers and the ground when the patient goes from standing upright with stretched knees to a maximum forward flexion of the torso. In the case of normal persons, this index is "O".

Results
Following the comparison of the initial and final pain of the patients from the experimental group with the help of the Student test, a $p<0.01$ value was obtained, which indicates a very significant statistically reduction. Furthermore, an important reduction of the final pain was noticed, as opposed to the initial pain, which results in an average difference of $5.97 \pm 0.69$ (from $6.42 \pm 0.53$ at the beginning of the treatment, to $0.57 \pm 0.53$ at the end of the treatment). (table III and table IV)

Following the comparison of the initial and final pain of the patients from the control group with the help of the Student test, a $p<0.01$ value was obtained, which indicates a very significant statistically reduction.

Table III. Pain evaluation with VAS - experimental group

\begin{tabular}{|c|c|c|c|c|c|}
\hline \multirow[b]{2}{*}{ No. } & \multirow[b]{2}{*}{ Initials } & \multicolumn{3}{|c|}{ Low back pain } & \multirow{2}{*}{$\begin{array}{l}\text { Difference between initial and } \\
\text { final assessment of pain }\end{array}$} \\
\hline & & Initial & Intermediate & Final & \\
\hline 1 & II & 7 & 4 & 0 & 7 \\
\hline 2 & RA & 6 & 3 & 1 & 5 \\
\hline 3 & SI & 7 & 4 & 1 & 6 \\
\hline 4 & $\mathrm{CL}$ & 6 & 3 & 0 & 6 \\
\hline 5 & IE & 6 & 3 & 1 & 5 \\
\hline 6 & MD & 7 & 4 & 1 & 6 \\
\hline 7 & $\mathrm{RP}$ & 6 & 3 & 0 & 6 \\
\hline Mean $\pm S D$ & & $6.42 \pm 0.53$ & $3.42 \pm 0.53$ & $0.57 \pm 0.53$ & $5.97 \pm 0.69$ \\
\hline
\end{tabular}

Table IV . Pain evaluation with VAS - control group

\begin{tabular}{|c|c|c|c|c|c|}
\hline No. & Initials & Initial & $\begin{array}{l}\text { Low back pain } \\
\text { Intermediate }\end{array}$ & Final & $\begin{array}{l}\text { Difference between initial and } \\
\text { final assessment of pain }\end{array}$ \\
\hline 1 & BA & 7 & 5 & 3 & 4 \\
\hline 2 & $\mathrm{CA}$ & 7 & 4 & 2 & 5 \\
\hline 3 & SR & 6 & 4 & 2 & 4 \\
\hline 4 & $\mathrm{LC}$ & 7 & 4 & 2 & 5 \\
\hline $\begin{array}{c}5 \\
\text { Mean } \pm S D\end{array}$ & TA & $\begin{array}{c}8 \\
7 \pm 0.70\end{array}$ & $\begin{array}{c}6 \\
4.6 \pm 0.89\end{array}$ & $\begin{array}{c}3 \\
2.4 \pm 0.54\end{array}$ & $\begin{array}{c}5 \\
4.6 \pm 0.54\end{array}$ \\
\hline
\end{tabular}

Furthermore, an important reduction of the final pain was noticed, as opposed to the initial paint, which results in an average difference of $4.6 \pm 0.54$ (from $7 \pm 0.70$ at the beginning of the treatment, to $2.4 \pm 0.54$ at the end of the treatment).

By comparing the final values of the pain's evaluation in the case of the two groups of patients with the help of the Student test, a value of $p<0.01$ was obtained, which indicates a very significant Table V. Finger to ground index - experimental group statistically reduction of the pain in case of the experimental group.

By comparing the final and initial values of the patients' finger to ground index, a value of $p<0.01$ was obtained, which indicates a very significant improvement. A significant statistically improvement was obtained when the initial and final values of these indexes where compared in the case of the patients from the control group $(p<0.05)$. (table $V)$ 


\begin{tabular}{|c|c|c|c|c|c|}
\hline \multirow[b]{2}{*}{ No. } & \multirow[b]{2}{*}{ Initials } & \multirow[b]{2}{*}{ Gender } & \multicolumn{2}{|c|}{ Finger to ground index (cm) } & \multirow[b]{2}{*}{ Difference } \\
\hline & & & Initial & Final & \\
\hline 1. & I.I. & $\mathrm{M}$ & 9 & 0 & 9 \\
\hline 2. & R.A. & M & 25 & 5 & 20 \\
\hline 3. & S.I. & M & 20 & 3 & 17 \\
\hline 4. & C.L. & $\mathrm{F}$ & 13 & 0 & 13 \\
\hline 5. & I.E. & $\mathrm{F}$ & 9 & 0 & 9 \\
\hline 6. & M.D. & M & 15 & 4 & 11 \\
\hline \multirow[t]{2}{*}{$\begin{array}{c}7 . \\
\text { Mean } \pm \text { SD }\end{array}$} & R.P. & $\mathrm{F}$ & $\begin{array}{c}20 \\
15.85 \pm 6.06\end{array}$ & $\begin{array}{c}5 \\
2.42 \pm 2.37\end{array}$ & $\begin{array}{c}15 \\
13.42 \pm 4.15\end{array}$ \\
\hline & & \multicolumn{4}{|c|}{$p<0.01$} \\
\hline
\end{tabular}

Table VI. Finger to ground index - control group

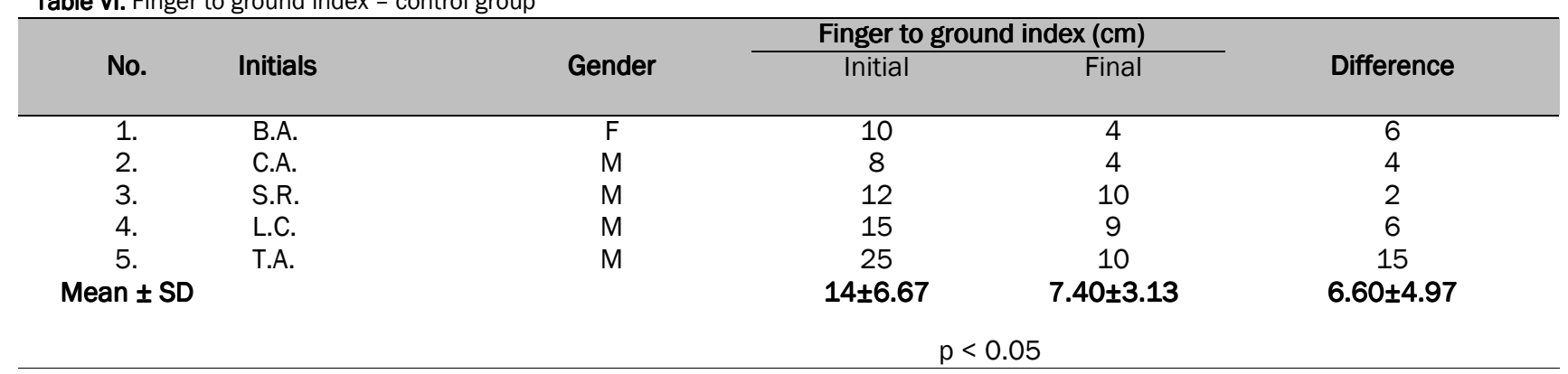

Still, by comparing the final values of the finger to ground index in the case of the two groups (experimental and control) with the help of the Student test, a significant statistically improvement was obtained in the case of the experimental group, as opposed to the control group $(p=0.0197$, p<0.05). (table VI)

\section{Discussions}

The mechanism by which reflexology acts on some distal areas or organs, with profound physiological effects, is not precisely known. Still, there are a series of theories such as: peripheral vasodilatation (which allows the removal of local accumulations of toxins), the "gate" theory which explains the reduction of the perception of pain, the placebo effect (involved in relaxation), therapeutic interacttion, the impact of touch of the tegument by the therapist (with release of endorphins and enkephalins which produces pain reduction and installation of a positive state) and the theory of the nervous impulse (the opening of ionic canals from the plasmatic membranes, under the pressure applied on the cellular receptors, and with the onset of local action potentials). [4, 5]

A current theory is that of electromagnetism, which is based on the assumption that our biological rhythms depend on the interaction of the electrical brain waves with the Earth's electromagnetic field. [8]. Another theory which tries to explain the effects of reflexology is the gravitational one, which state that serum deposits of calcium and uric acid accumulate due to gravity at the level of the foot (in the areas corresponding to the affected organs). These deposits can be diagnosed, beeing painful on palpation, and also can be mobilized and dispersed through reflexology, helping to restore body homeostasis. [2, 8]

Our findings are similar to those in the literature. Thus, Quinn F. et al [9] have investigated the effectiveness of reflexology in the management of low back pain in a trial with 15 participants, randomised in two groups: reflexology group and 
sham group. Following reflexology was obtained an important reduction in average pain assessed by VAS (Visual Analogue Scale) in the reflexology group. Also, McGill pain questionnaire scores indicated a reduction in low back pain in both groups. Similar effect of reflexology on chronic back pain intensity was obtained by Eghbali M. et al [10] in a double blind clinical trial with 50 nurses (female and male). Pain intensity was measured using a numeric analogue scale for pain. The result of this trial showed a significantly reduction in pain intensity scores in the group who received a reflexology treatment. On the other hand, there are studies in the literature which showing only insignificant influence of reflexology in chronic back pain. Thus, Poole $\mathrm{H}$. et al [7] in a controlled trial with 243 participants with chronic back pain (randomised in three groups - reflexology, relaxation and usual care) show that reflexology is no more effective than usual care alone. Moreover, there was a greater pain intensity reduction in the reflexology group, but not significantly different from the others groups.

\section{Conclusions}

One of the important indications of reflexology is low back pain. This alternative therapy must be used at the same time with classic methods of treatment, with the aim of obtaining better results.

In the case of the groups of patients studied by us, following the application of reflexology techniques, combined with drug therapy in some conditions which determine low back pain, a very significant statistically reduction of the pain has been produced $(p<0.01)$. Moreover, reflexology combined with drug therapy determined a very significant statistically improvement of the finger to ground index $(p<0.01)$ in the case of patients from the experimental group. Both in the case of the patients from the experimental group, and in the case of the patients from the control group, statistically significant reductions of the final pain as opposed to the initial pain took place $(p<0.01)$, while strong statistically significant reductions of the finger to ground index values $(p<0.01)$ also took place, the improvement of this index for the patients from the control group was only statistically significant $(p<0.05)$.

Due to the small number of patients involved in the study, the data obtained cannot be generalised; still, numerous studies which support these results can be found in the scientific literature. Further studies are required to certify the importance of reflexology in diverse pathologies, including in the case of lower back pain.

\section{References}

1. Chiruță I., Postolică V. (2006) Incursiuni în reflexoterapie. Sănătate prin masaje şi remedii naturiste. Editura Corint, Bucureşti;

2. Bliss J., Bliss G. (2000) How does reflexology work? Theories on why it does work. Reflexology Association of California;

3. Piquemal M. (2005) Global effect of reflexology on blood flow, presented at the " $10^{\text {th }}$ ICR International Conference, Amsterdam, September 2005;

4. Marquardt H. (2000) Reflexotherapy of the feet. Thieme: Stuttgart;

5. Tiran D., Chummun H. (2005) The physiological basis of reflexology and its use as a potential diagnostic tool. Complementary Therapies in Clinical Practice, 11 (1): 58-64;

6. Lidell L. (2003), Masajul. Ghid practic de tehnici orientale şi occidentale, Ed. Pro Editura, București;

7. Poole H., Glenn S., Murphy P. (2007) A randomized controlled study of reflexology for the treatment of chronic low back pain. European Journal of Pain, 11: 878-887;

8. Saunders T. (2003) Health hazards and electromagnetic fields. Compl. Ther. Nurs Midwifery, 9(4): 191-197;

9. Quinn F., Hughes CM, Baxter GD (2008) Reflexology in the management of low back pain: a pilot randomized controlled trial. Complementary Therapies in Medicine, 16: 3-8;

10. Eghbali M., Safari R., Nazari F., Abdoli S. (2012) The effects of reflexology on chronic low back pain intensity in nurses employed in hospitals affiliated with Isfahan University of Medical Sciences. Iranian Journal of Nursing and Midwifery Research, 17(3): 239243. 